\title{
Effect of glucocorticoid excess on skeletal muscle and heart protein synthesis in adult and old rats
}

\author{
Isabelle Savary*, Elisabeth Debras, Dominique Dardevet, Claire Sornet, Pierre Capitan, \\ Jacques Prugnaud, Philippe Patureau Mirand and Jean Grizard \\ Unité d'Etude du Métabolisme Azoté, Institut National de la Recherche Agronomique, \\ Centre de Recherches de Clermont-Ferrand Theix, 63122 Ceyrat, France
}

(Received 14 July 1997 - Revised 22 September 1997 - Accepted 6 October 1997)

\begin{abstract}
This study was carried out to analyse glucocorticoid-induced muscle wasting and subsequent recovery in adult (6-8 months) and old (18-24 months) rats because the increased incidence of various disease states results in hypersecretion of glucocorticoids in ageing. Adult and old rats received dexamethasone in their drinking water for 5 or $6 \mathrm{~d}$ and were then allowed to recover for 3 or $7 \mathrm{~d}$. As dexamethasone decreased food intake, all groups were pair-fed to dexamethasonetreated old rats (i.e. the group that had the lowest food intake). At the end of the treatment, adult and old rats showed significant increases in blood glucose and plasma insulin concentrations. This increase disappeared during the recovery period. Protein synthesis of different muscles was assessed in vivo by a flooding dose of $\left[{ }^{13} \mathrm{C}\right]$ valine injected subcutaneously $50 \mathrm{~min}$ before slaughter. Dexamethasone induced a significant decrease in protein synthesis in fast-twitch glycolytic and oxidative glycolytic muscles (gastrocnemius, tibialis anterior, extensor digitorum longus). The treatment affected mostly ribosomal efficiency. Adult dexamethasone-treated rats showed an increase in protein synthesis compared with their pair-fed controls during the recovery period whereas old rats did not. Dexamethasone also significantly decreased protein synthesis in the predominantly oxidative soleus muscle but only in old rats, and increased protein synthesis in the heart of adult but not of old rats. Thus, in skeletal muscle, the catabolic effect of dexamethasone is maintained or amplified during ageing whereas the anabolic effect in heart is depressed. These results are consistent with muscle atrophy occurring with ageing.
\end{abstract}

Ageing: Glucocorticoids: Muscle: Protein synthesis

A loss of skeletal muscle mass begins after 30 years of age in human subjects (Cohn et al. 1980) and leads to an alteration of the capacity of elderly human beings to respond successfully to stressful situations (Young et al. 1989). Such a loss has also been described after 12 months in rat hind-limb muscles (Holloszy et al. 1991; Mosoni et al. 1993). It results from an imbalance between protein synthesis and degradation rates. This imbalance, however, is not clearly apparent when basal rates of protein turnover are measured (Mosoni et al. 1993) but can be detected in rats during the postprandial period or endurance training (Mosoni et al. 1995). Mechanisms underlying changes in the regulation of muscle protein turnover during ageing are still partially unknown.
Glucocorticoid hormones have been demonstrated to be involved in the ageing process since adrenalectomy attenuates the development of age-specific effects. Correlated impairments in the neuroendocrine system (e.g. hippocampus) and elevated glucocorticoid levels accelerate these impairments (Landfield et al. 1981). Sapolsky et al. (1986) proposed the glucocorticoid cascade hypothesis of ageing which is based on the concept that neurons in the hippocampus containing a high density of steroid-hormone receptors are involved in the regulation of both glucocorticoid secretion (through negative feedback) and action (see Masoro, 1995 for a review). Decreases in the number of these receptors during ageing are consistent with the increase in basal glucocorticoid secretion observed in

\footnotetext{
Abbreviations: APE, atoms percent excess; ASR, absolute synthesis rate; Dex, dexamethasone; eIF, eukaryotic initiation factor; FSR, fractional synthesis rate; $R+3,3 \mathrm{~d}$ recovery period; $R+7,7 \mathrm{~d}$ recovery period; $S$, stage of experiment; $T$, treatment.

*Corresponding author: Mlle Isabelle Savary, fax +334736247 55, email Savary@clermont.inra.fr
} 
many studies and the apparently greater responses to glucocorticoid excess in some variables (see Mobbs, 1996 for a review). Moreover, the fact that the return of circulating corticosterone to basal level is slowed down in old, stressed rats (due to a decrease in the metabolic clearance of the hormone) may also increase glucocorticoid action in old subjects (Sapolsky et al. 1983).

The association of glucocorticoid excess and muscle atrophy is well established, at least in growing rats (Rannels \& Jefferson, 1980; Kelly \& Goldspink, 1982; Odedra et al. 1983). An inhibition of protein synthesis has been consistently observed in glucocorticoid-treated animals (Odedra et al. 1983). An effect of glucocorticoids on skeletal muscle protein breakdown has also been reported (Tomas et al. 1979; Bowes et al. 1996) but not in all studies (Odedra \& Millward, 1982).

In a previous study, using epitrochlearis muscle in vitro, old rats were more sensitive to the effect of glucocorticoids but showed a decreased ability to recover (Dardevet $e t$ al. 1995). However epitrochlearis muscle contains a very high proportion of oxidative glycolytic fibres. The effect of glucocorticoids on muscle protein synthesis is highly dependent on the type of muscle considered. Usually, the decrease in protein synthesis observed after glucocorticoid treatment in growing rats occurs in oxidative glycolytic and glycolytic muscles (Kelly \& Goldspink, 1982) but not in oxidative muscles. Moreover, glucocorticoids stimulate protein synthesis in heart (Kelly et al. 1986).

For a better understanding of the role of glucocorticoids in muscle atrophy during ageing, we analysed here the effect of dexamethasone on protein synthesis in vivo in various skeletal muscles from adult and old rats.

\section{Materials and methods}

\section{Animals}

These experiments were made in accordance with current legislation on animal experiments in France. Adult (6-8 months) and old (18 months) male Sprague-Dawley rats were purchased from Iffa-Credo (L'Arbresle, France) and housed under controlled environmental conditions (temperature $22^{\circ} ; 12 \mathrm{~h}$ dark period starting at 18.00 hours). Rats were given free access to commercial laboratory chow (UAR, Epinay sur Orge, France) (g/kg: protein 220, fat 40, cellulose 40 , carbohydrate 520 , minerals 60 , water 120 , vitamin $\mathrm{A}$, cholecalciferol and vitamin $\mathrm{E}$ ) and water before the experiments were performed. Both adult and old rats were randomly divided into a control and a dexamethasone (Dex)-treated group (adult rats: $n 24$ Dex-treated and $n 24$ controls; old rats: $n 15$ Dex-treated and $n 15$ controls). Dex (a synthetic glucocorticoid analogue that does not bind to plasma binding proteins) was given daily (at 09.00 hours) in the drinking water. Dex concentration was adjusted every day on the basis of drinking water intake the day before. Adult and old animals received throughout the treatment period 543 (SE 101) and 564 (SE 68) $\mu \mathrm{g} / \mathrm{kg}$ body weight per $\mathrm{d}$ respectively. As Dex has been reported to decrease food intake, all groups were pair-fed to the group that had the lowest food intake (i.e. Dex-treated old rats). Dex was given for $5 \mathrm{~d}$ to old rats but for $6 \mathrm{~d}$ to adult rats in order to generate a similar muscle atrophy in both groups, since muscle wasting was more rapid in aged animals (Dardevet et al. 1995). Rats were allowed to recover for either $3(\mathrm{R}+3)$ or $7(\mathrm{R}+7) \mathrm{d}$.

\section{Measurement of protein synthesis rates, killing and sampling}

Protein synthesis rates were measured in vivo using the flooding dose method (Garlick et al. 1980), which reduces uncertainty over the labelling of the tracer amino acid in the precursor pool for protein synthesis. Briefly, $50 \mathrm{~min}$ before slaughter, each rat was injected subcutaneously (time 0 ) with a flooding dose of valine $(300 \mu \mathrm{mol} / 100 \mathrm{~g}$ body weight) to flood the precursor pools. L-Valine $\left[1-{ }^{13} \mathrm{C}\right](99$ atoms $\%{ }^{13} \mathrm{C}$, Mass Trace, Woburn, MA, USA) was used as a tracer and the enrichment of the flooding dose was 50 atoms percent excess (APE). In preliminary experiments, Mosoni et al. (1995) verified that enrichment in tissue was similar in different organs and remained nearly constant during incorporation time. In that experiment, free valine specific activity reached a high value in plasma and in muscle (soleus) of adult (12 months) and old (19 months) rats $10 \mathrm{~min}$ after injection of the same flooding dose (greater than $80 \%$ of the specific activity of the injected valine) and remained constant thereafter (up to $55 \mathrm{~min}$ after injection).

General anaesthesia was induced by subcutaneous injection of pentobarbital sodium (Sanofi, Libourne, France; $6 \mathrm{mg} / \mathrm{kg}$ body weight), $5 \mathrm{~min}$ before killing. Rats were exsanguinated and blood was collected in heparinized tubes which were centrifuged. Plasma was collected and frozen. Gastrocnemius, soleus, extensor digitorum longus, tibialis anterior muscles of both legs and heart, were quickly excised. All tissues were weighed and frozen in liquid $\mathrm{N}_{2}$ within 2-5 min after exsanguination.

\section{Analytical methods}

To extract tissue free amino acids, frozen tissues were homogenized in 7 volumes of ice-cold $0.6 \mathrm{M}$-TCA. The acid-soluble fraction containing free amino acids was separated from the protein precipitate by centrifugation (10 $000 \mathrm{rev} . / \mathrm{min}$ for $15 \mathrm{~min}$ ). Proteins were resuspended in TCA and centrifuged. The acid-soluble fractions were combined. TCA was removed on a column of cationexchange resin (AG50X8, 100-200 mesh, $\mathrm{H}$ form, BioRad, Richmond, CA, USA). Amino acids, eluted with $4 \mathrm{M}$ $\mathrm{NH}_{4} \mathrm{OH}$, were dried and resuspended in $0.1 \mathrm{M}-\mathrm{HCl}$ for free tissue valine enrichment determination which was performed by GC-mass spectrometry, with a HP 5972 organic mass spectrometer quadrupole coupled to a HP $5890 \mathrm{GC}$ (Hewlett Packard, Les Ulis, France). Valine was measured as the tertiary butyl-dimethylsilyl derivative under electron impact ionization. The ion $\mathrm{m} / \mathrm{z} 288$ and 289 were monitored by selective ion recording to determine the $\left[{ }^{13} \mathrm{C}\right]$ valine enrichment.

The tissue protein precipitates were washed twice with $0.6 \mathrm{M}$-TCA and once with $0.2 \mathrm{M}$-perchloric acid. The protein precipitates were dissolved in $0.1 \mathrm{M}-\mathrm{NaOH}$ and 
incubated for $1 \mathrm{~h}$ at $37^{\circ}$. A portion was used to measure tissue protein content according to Smith et al. (1985) by colorimetric reaction with bicinchoninic acid (Pierce, Rockford, IL, USA). Proteins dissolved in $0.1 \mathrm{M}-\mathrm{NaOH}$ were precipitated with 0.4 volumes of $2 \mathrm{M}$-perchloric acid, stored overnight at $4^{\circ}$, and centrifuged. The supernatant fraction was used to measure the RNA content by the method of Manchester \& Harris (1968). A portion of the tissue protein containing approximately $4 \mu \mathrm{mol}$ valine was hydrolysed in $6 \mathrm{M}-\mathrm{HCl}$ for $48 \mathrm{~h}$ at $110^{\circ}$ and dried. Valine was measured as $\mathrm{N}$-acetyl-propyl-amino acid. The ratio ${ }^{13} \mathrm{CO}_{2}:{ }^{12} \mathrm{CO}_{2}$ was measured with a gas isotope ratio spectrometer coupled with a GC (Isochrom II, Fisons, Manchester, UK).

Plasma insulin was determined by direct radioimmunoassay with a commercial kit (ERIA Diagnostic Pasteur, Sanofi, France). Blood glucose was assessed enzymically using glucose oxidase (EC 1.1.3.4; GOD-PAP method, Cobas Roche, Neuilly sur Seine, France).

\section{Calculations}

The fractional synthesis rates (FSR, \% per d) were calculated according to the method described by Garlick et al. $(1980)$ : $\mathrm{FSR}=100 \times(\mathrm{EP}-\mathrm{EN}) /(\mathrm{EA} \times \mathrm{t})$ where $\mathrm{t}$ is the incorporation time $(50 \mathrm{~min})$, expressed in days, EP is the enrichment of protein-bound valine at the time of killing, EN the natural enrichment of protein-bound valine in each organ considered, and EA the enrichment of tissue free valine. EP, EN and EA were expressed in APE by reference to the natural enrichment of valine obtained from Sigma Chemical Company (Saint Louis, MO, USA). Absolute synthesis rates (ASR) $(\mathrm{mg} / \mathrm{d})$ were calculated by multiplying FSR by total tissue protein content. Ribosomal capacity was estimated as the ratio total RNA : protein ( $\mu \mathrm{g}$ RNA/mg protein) because most of the RNA in tissues is ribosomal. Ribosomal efficiency was calculated as the ratio ASR : total RNA (mg protein/d per mg RNA).

\section{Statistical methods}

Values for food intake are given as means with their standard errors. The other values are given as means with the residual standard error (RSE) ( $n 9$ adult rats, $n 7$ old rats). All data were analysed separately for each age group by ANOVA (Statistical Analysis Systems, version 6.01, 1987; SAS Institute Inc., Cary, NC, USA) according to a two-way factorial model. The main effects tested were the treatment (T) and the stage at which animals were killed (S). The $T \times S$ interaction was included in the model. In case of significant $S$ or $T \times S$ effects, means were compared using Student's $t$ test.

\section{Results}

\section{Animal characteristics}

Food intake was maintained at similar levels in all groups during both Dex treatment and the recovery period (Fig. 1). Thus differences between groups do not originate from different intakes.

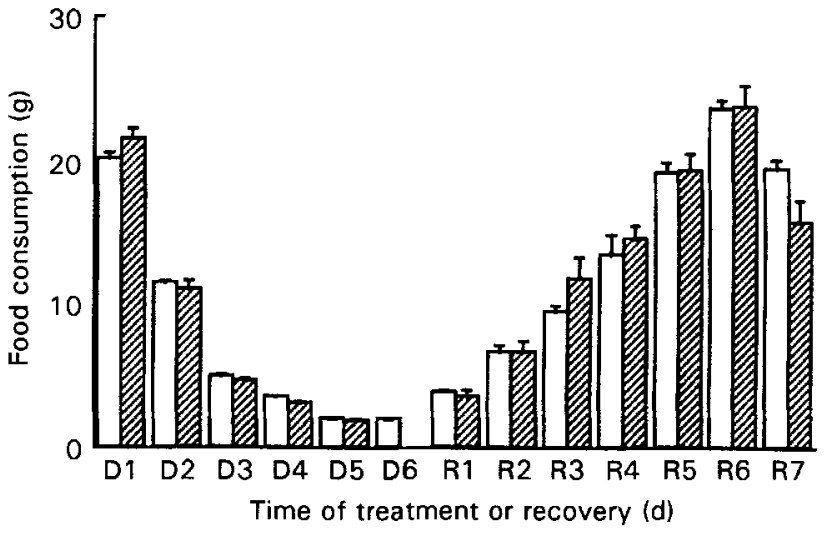

Fig. 1. Food intake of adult ( $\square$ ) and old (ש) rats during treatment with dexamethasone (D) and during a subsequent recovery $(\mathrm{A})$ period. Values are means with their standard errors represented by vertical bars for twenty-four adult and fifteen old rats during the treatment period, fifteen adult and eight old rats on days R1, R2 and $R 3$, and eight adult and four old rats from R4 to R7. For details of procedures see p. 298.

Dex treatment induced similar body-weight losses in old and adult rats (-117 (SE 17) $\mathrm{g}$ and -99 (SE 20) $\mathrm{g}$ respectively). At the beginning of treatment, the weights of adult rats were 588 (SE 12) g and 568 (SE 12) $\mathrm{g}$ for Dextreated and pair-fed groups respectively, but after $6 \mathrm{~d}$ of treatment, the weights were 471 (SE 11) g and 501 (SE 12) g. At the beginning of treatment, the weights of old rats were 636 (SE 15) $\mathrm{g}$ and 644 (SE 17) $\mathrm{g}$ for Dex-treated and pair-fed groups respectively but after $5 \mathrm{~d}$ of treatment the weights were 537 (SE 13) g and 594 (SE 6) g.

Fast-twitch glycolytic and oxidative glycolytic muscles showed a significant loss of protein at the end of Dex treatment in adult rats $(-18.2,-17.5,-16.2 \%$ in gastrocnemius, tibialis anterior and extensor digitorum longus respectively, $P<0.05 v$. pair-fed controls (Table 1 ). The difference between Dex and control adult rats was only significant at the end of the Dex treatment for extensor digitorum longus and tibialis anterior but remained significant in gastrocnemius until $R+7(-12.9$ and $-12.7 \% v$. control at $R+3$ and $R+7$ respectively, $P<0.05)$. The pattern of change in muscle protein content of old rat muscles differed from that observed in adult rats. Indeed, no significant loss of protein due to Dex treatment was visible at the end of the treatment. A loss of protein between Dex and control old rats only occurred during the recovery period at $\mathrm{R}+3$ in tibialis anterior $(-18.4 \% v$. control, $P<0.05)$ and at $\mathrm{R}+7$ in gastrocnemius and extensor digitorum longus ( -22.2 and $-25.9 \% \mathrm{v}$. control, $P<0.05$ respectively).

Contrasting with glycolytic and oxidative glycolytic muscles, the protein content of oxidative muscles was not generally significantly modified (the significant increase in heart from adult rats at $R+3$ was an exception) (Table 2).

At the end of the treatment period, both adult and old rats showed significant increases $(P<0.05)$ in plasma glucose and insulin when compared with their pair-fed controls (Table 3).

Both the hyperglycaemic and hyperinsulinaemic effects of Dex were similar in adult and old rats. During the 
Table 1. Protein content and ribosomal capacity of oxidative glycolytic and glycolytic skeletal muscles in adult and old rats given dexamethasone (Dex) in their drinking water for 6 and $5 \mathrm{~d}$ respectively, and in pair-fed controls; animals were killed at the end of the treatment (DEX) or allowed to recover for $3(R+3)$ or $7(R+7) d$

(Values are means and residual standard errors of three stage(s) for the two treatments $(T)$ )

\begin{tabular}{|c|c|c|c|c|c|c|c|c|c|c|c|c|c|c|c|}
\hline & & \multicolumn{4}{|c|}{ Protein content (mg) } & \multicolumn{3}{|c|}{ ANOVA: $P<$} & \multicolumn{4}{|c|}{$\begin{array}{l}\text { Ribosomal capacity } \\
\text { ( } \mu \text { g RNA/mg protein) }\end{array}$} & \multicolumn{3}{|c|}{ ANOVA: $P<$} \\
\hline & & DEX & $\mathrm{R}+3$ & $R+7$ & RSE & $\mathrm{T}$ & S & $T \times S$ & DEX & $\mathrm{R}+3$ & $R+7$ & RSE & $\mathrm{T}$ & S & $T \times S$ \\
\hline \multicolumn{16}{|c|}{ Gastrocnemius } \\
\hline Adult & $\begin{array}{l}\text { Control } \\
\text { Dex }\end{array}$ & $\begin{array}{l}583(n 9) \dagger \\
477^{* *}(n 9)\end{array}$ & $\begin{array}{l}466(n 7) \\
405^{*}(n 7)\end{array}$ & $\begin{array}{l}480(n 8) \\
419^{\star}(n 8)\end{array}$ & 18 & 0.01 & 0.01 & NS & $\begin{array}{l}3.75 \\
3.31\end{array}$ & $\begin{array}{l}3.59 \\
4.03\end{array}$ & $\begin{array}{l}3.86 \\
4.98^{\star \star}\end{array}$ & 0.19 & 0.01 & 0.05 & 0.01 \\
\hline Old & $\begin{array}{l}\text { Control } \\
\text { Dex }\end{array}$ & $\begin{array}{l}516(n 7) \\
493(n 7)\end{array}$ & $\begin{array}{l}603(n 4) \\
532(n 4)\end{array}$ & $\begin{array}{l}512(n 4) \\
398^{(*)}(n 4)\end{array}$ & 31 & 0.05 & 0.05 & NS & $\begin{array}{l}4.91 \\
4.30\end{array}$ & $\begin{array}{l}4 \cdot 23 \\
5 \cdot 31^{*}\end{array}$ & $\begin{array}{l}4.52 \\
5.23\end{array}$ & 0.27 & NS & NS & 0.05 \\
\hline \multicolumn{16}{|l|}{ Tibialis } \\
\hline Adult & $\begin{array}{l}\text { Control } \\
\text { Dex }\end{array}$ & $\begin{array}{l}212 \\
175^{* *}\end{array}$ & $\begin{array}{l}186 \\
171\end{array}$ & $\begin{array}{l}193 \\
177\end{array}$ & 8 & 0.01 & NS & NS & $\begin{array}{l}3.53 \\
2.95^{* *}\end{array}$ & $\begin{array}{l}3.35 \\
3.43\end{array}$ & $\begin{array}{l}3 \cdot 73 \\
4.29^{* \star}\end{array}$ & 0.10 & NS & 0.01 & 0.01 \\
\hline Old & $\begin{array}{l}\text { Control } \\
\text { Dex }\end{array}$ & $\begin{array}{l}180 \\
170\end{array}$ & $\begin{array}{l}190 \\
155^{*}\end{array}$ & $\begin{array}{l}174 \\
150\end{array}$ & 9 & 0.05 & NS & NS & $\begin{array}{l}5.05 \\
4.70\end{array}$ & $\begin{array}{l}5.39 \\
5.07\end{array}$ & $\begin{array}{l}6.34 \\
6 \cdot 23\end{array}$ & 0.20 & NS & 0.01 & NS \\
\hline \multicolumn{16}{|c|}{ Extensor digitorum longus } \\
\hline Adult & $\begin{array}{l}\text { Control } \\
\text { Dex }\end{array}$ & $\begin{array}{l}51 \\
43^{\star \star}\end{array}$ & $\begin{array}{l}45 \\
42\end{array}$ & $\begin{array}{l}46 \\
41\end{array}$ & 2 & 0.01 & NS & NS & $\begin{array}{l}3.36 \\
3.14\end{array}$ & $\begin{array}{l}3.20 \\
3.26\end{array}$ & $\begin{array}{l}3.57 \\
3.74\end{array}$ & 0.10 & NS & 0.01 & NS \\
\hline Old & $\begin{array}{l}\text { Control } \\
\text { Dex }\end{array}$ & $\begin{array}{l}46 \\
43\end{array}$ & $\begin{array}{l}46 \\
44\end{array}$ & $\begin{array}{l}54 \\
40^{\star *}\end{array}$ & 2 & 0.01 & NS & NS & $\begin{array}{l}4.45 \\
4.20\end{array}$ & $\begin{array}{l}4.22 \\
4.31\end{array}$ & $\begin{array}{l}4.36 \\
4.33\end{array}$ & 0.14 & NS & NS & NS \\
\hline
\end{tabular}

Mean values were significantly different from those for the control group at the same stage: ${ }^{*} P<0.05,{ }^{* \star} P<0.01,{ }^{(*)} P<0.06$.

$\dagger$ The values for $n$ given for gastrocnemius muscle are the same for the other variables in this muscle and for the other muscles at the same stage of slaughter in the same treatment group.

Table 2. Protein content and ribosomal capacity of oxidative muscles in adult and old rats given dexamethasone (Dex) in their drinking water for 6 and $5 \mathrm{~d}$ respectively, and in pair-fed controls; animals were killed at the end of the treatment (DEX) or allowed to recover for $3(\mathrm{R}+3)$ or $7(R+7) d$

(Values are means and residual standard errors of three stages $(S)$ for the two treatments $(T)$ )

\begin{tabular}{|c|c|c|c|c|c|c|c|c|c|c|c|c|c|c|c|}
\hline & & \multicolumn{4}{|c|}{ Protein content (mg) } & \multicolumn{3}{|c|}{ ANOVA: $P<$} & \multicolumn{4}{|c|}{$\begin{array}{l}\text { Ribosomal capacity } \\
\text { ( } \mu \mathrm{g} \text { RNA/mg protein) }\end{array}$} & \multicolumn{3}{|c|}{ ANOVA: $P<$} \\
\hline & & DEX & $R+3$ & $R+7$ & RSE & $\mathrm{T}$ & $\mathrm{S}$ & $T \times S$ & DEX & $\mathrm{A}+3$ & $\mathrm{R}+7$ & RSE & $\mathrm{T}$ & $S$ & $T \times S$ \\
\hline \multicolumn{16}{|l|}{ Soleus } \\
\hline Adult & $\begin{array}{l}\text { Control } \\
\text { Dex }\end{array}$ & $\begin{array}{l}40(n 9) \dagger \\
39(n 9)\end{array}$ & $\begin{array}{l}38(n 7) \\
43(n 7)\end{array}$ & $\begin{array}{l}38(n 8) \\
39(n 8)\end{array}$ & 2 & NS & NS & NS & $\begin{array}{l}7.35 \\
6.78\end{array}$ & $\begin{array}{l}7.31 \\
7.22\end{array}$ & $\begin{array}{l}7.07 \\
7.38\end{array}$ & 0.21 & NS & NS & NS \\
\hline Old & $\begin{array}{l}\text { Control } \\
\text { Dex }\end{array}$ & $\begin{array}{l}36(n 7) \\
39(n 7)\end{array}$ & $\begin{array}{l}40(n 4) \\
47(n 4)\end{array}$ & $\begin{array}{l}44(n 4) \\
41(n 4)\end{array}$ & 2 & NS & 0.05 & NS & $\begin{array}{l}9.50 \\
8.84\end{array}$ & $\begin{array}{l}9.64 \\
8.71\end{array}$ & $\begin{array}{l}9.89 \\
9.43\end{array}$ & 0.30 & 0.05 & NS & NS \\
\hline \multicolumn{16}{|l|}{ Heart } \\
\hline Adult & $\begin{array}{l}\text { Control } \\
\text { Dex }\end{array}$ & $\begin{array}{l}254 \\
278\end{array}$ & $\begin{array}{l}203 \\
257^{\star}\end{array}$ & $\begin{array}{l}218 \\
246\end{array}$ & 13 & 0.01 & 0.05 & NS & $\begin{array}{l}7 \cdot 26 \\
7 \cdot 18\end{array}$ & $\begin{array}{l}7.21 \\
7.71\end{array}$ & $\begin{array}{l}8.40 \\
8.69\end{array}$ & 0.40 & NS & 0.01 & NS \\
\hline Old & $\begin{array}{l}\text { Control } \\
\text { Dex }\end{array}$ & $\begin{array}{l}283 \\
300\end{array}$ & $\begin{array}{l}272 \\
260\end{array}$ & $\begin{array}{l}226 \\
243\end{array}$ & 16 & NS & 0.05 & NS & $\begin{array}{l}9.48 \\
8.83\end{array}$ & $\begin{array}{l}9.19 \\
8.91\end{array}$ & $\begin{array}{l}9.43 \\
9.25\end{array}$ & 0.29 & NS & NS & NS \\
\hline
\end{tabular}

Mean value was significantly different from that for the control group at the same stage, ${ }^{*} P<0.05$.

$\dagger$ The values for $n$ given for soleus muscle are the same for the other variables in this muscle and for heart at the same stage of slaughter in the same treatment group.

recovery period, Dex treatment effects on plasma glucose and insulin disappeared rapidly in adult and old rats although plasma insulin tended to be higher in old Dextreated rats.

\section{Fast-twitch glycolytic and oxidative glycolytic muscle protein metabolism}

A significant decrease in FSR (\% protein synthesized per d) was recorded in fast-twitch glycolytic and oxidative glycolytic muscles from both adult and old rats at the end of the Dex treatment (gastrocnemius -34.5 and $-56.1 \%$, tibialis anterior -39.7 and $-37.5 \%$, extensor digitorum longus -27.8 and $-24.9 \% v$. control, $P<0.05$, in adult and old rats respectively; Table 4). The FSR in gastrocnemius from Dex-treated adult rats increased above that of their controls after Dex withdrawal $(+34.0$ and $+34.5 \%$ $v$. control, $P<0.05$, at days 3 and 7 of recovery respectively). A similar phenomenon occurred in tibialis anterior and extensor digitorum longus but only at day 7 of recovery $(+24.4$ and $+12.3 \%$ v. control, $P<0.05$ respectively). Contrasting with adults, old rats did not 
Table 3. Plasma glucose and insulin concentrations in adult and old rats given dexamethasone (Dex) in their drinking water for 6 and $5 \mathrm{~d}$ respectively, and in pair-fed controls; animals were killed at the end of the treatment (DEX) or allowed to recover for $3(R+3)$ or $7(R+7) d$

(Values are means and residual standard errors of three stages (S) for the two treatments (T))

\begin{tabular}{|c|c|c|c|c|c|c|c|c|}
\hline & & \multirow[b]{2}{*}{ DEX } & \multirow[b]{2}{*}{$\mathrm{R}+3$} & \multirow[b]{2}{*}{$R+7$} & \multirow[b]{2}{*}{ RSE } & \multicolumn{3}{|c|}{ ANOVA: $P<$} \\
\hline & & & & & & $\mathrm{T}$ & $S$ & $\mathrm{~T} \times \mathrm{S}$ \\
\hline \multicolumn{9}{|c|}{ Plasma glucose $(\mathrm{g} / \mathrm{l})$} \\
\hline Adult & $\begin{array}{l}\text { Control } \\
\text { Dex }\end{array}$ & $\begin{array}{l}1.6(n 9) \dagger \\
4.6^{\star \star}(n 9)\end{array}$ & $\begin{array}{l}1.8(n 7) \\
1.4(n 7)\end{array}$ & $\begin{array}{l}2.1(n 8) \\
1.6(n 8)\end{array}$ & 0.9 & 0.05 & 0.01 & 0.01 \\
\hline Old & $\begin{array}{l}\text { Control } \\
\text { Dex }\end{array}$ & $\begin{array}{l}1.6(n 7) \\
4.6^{\star \star}(n 7)\end{array}$ & $\begin{array}{l}2.0(n 4) \\
1.8(n 4)\end{array}$ & $\begin{array}{l}1.9(n 4) \\
1.7(n 4)\end{array}$ & 0.3 & 0.01 & 0.01 & 0.01 \\
\hline \multicolumn{9}{|c|}{ Plasma insulin $(\mu \mathrm{U} / \mathrm{ml})$} \\
\hline Adult & $\begin{array}{l}\text { Control } \\
\text { Dex }\end{array}$ & $\begin{array}{c}21 \\
179^{\star \star}\end{array}$ & $\begin{array}{l}36 \\
59\end{array}$ & $\begin{array}{l}59 \\
85\end{array}$ & 12 & 0.01 & 0.01 & 0.01 \\
\hline Old & $\begin{array}{l}\text { Control } \\
\text { Dex }\end{array}$ & $\begin{array}{c}51 \\
249^{* *}\end{array}$ & $\begin{array}{r}71 \\
134\end{array}$ & $\begin{array}{r}75 \\
105\end{array}$ & 33 & 0.01 & NS & NS \\
\hline
\end{tabular}

Mean values were significantly different from those for the control group at the same stage, ${ }^{* *} P<0.01$.

+ The values for $n$ given for glucose are the same for insulin at the same stage of slaughter in the same treatment group.

Table 4. Fractional synthesis rates (FSR) and ribosomal efficiency of oxidative glycolytic and glycolytic skeletal muscles in adult and old rats given dexamethasone (Dex) in their drinking water for 6 and $5 \mathrm{~d}$ respectively, and in pair-fed controls; animals were killed at the end of treatment (DEX) or allowed to recover for $3(\mathrm{~A}+3)$ or $7(\mathrm{~A}+7) \mathrm{d}$

(Values are means and residual standard errors of three stages $(\mathrm{S})$ for the two treatments $(\mathrm{T})$ )

\begin{tabular}{|c|c|c|c|c|c|c|c|c|c|c|c|c|c|c|c|}
\hline & & \multicolumn{4}{|c|}{ FSR (\% per d) } & \multicolumn{3}{|c|}{ ANOVA: $P<$} & \multicolumn{4}{|c|}{$\begin{array}{c}\text { Ribosomal efficiency } \\
\text { (mg protein/mg RNA per d) }\end{array}$} & \multicolumn{3}{|c|}{ ANOVA: $P<$} \\
\hline & & DEX & $R+3$ & $R+7$ & RSE & $T$ & $S$ & $\mathrm{~T} \times \mathrm{S}$ & DEX & $R+3$ & $R+7$ & RSE & $\mathrm{T}$ & $\mathrm{S}$ & $T \times S$ \\
\hline \multicolumn{16}{|c|}{ Gastrocnemius } \\
\hline Adult & $\begin{array}{l}\text { Control } \\
\text { Dex }\end{array}$ & $\begin{array}{l}2.73(n 9) \dagger \\
1.79^{\star \star}(n 9)\end{array}$ & $\begin{array}{l}2.56(n 7) \\
3.43^{*}(n 7)\end{array}$ & $\begin{array}{l}3.65(n 8) \\
4.91^{\star \star}(n 8)\end{array}$ & 0.22 & 0.05 & 0.01 & 0.01 & $\begin{array}{l}7 \cdot 37 \\
5 \cdot 34^{\star \star}\end{array}$ & $\begin{array}{l}7.13 \\
8.59\end{array}$ & $\begin{array}{l}9.47 \\
9.91\end{array}$ & 0.51 & NS & 0.01 & 0.01 \\
\hline Old & $\begin{array}{l}\text { Control } \\
\text { Dex }\end{array}$ & $\begin{array}{l}3.51(n 7) \\
1.54^{\star \star}(n 7)\end{array}$ & $\begin{array}{l}2.63(n 4) \\
3.18(n 4)\end{array}$ & $\begin{array}{l}2.60(n 4) \\
3.47(n 4)\end{array}$ & 0.27 & NS & NS & 0.01 & $\begin{array}{l}7.05 \\
3.42^{* *}\end{array}$ & $\begin{array}{l}6.24 \\
6.01\end{array}$ & $\begin{array}{l}5 \cdot 77 \\
6 \cdot 66\end{array}$ & 0.38 & 0.05 & NS & 0.01 \\
\hline \multicolumn{16}{|c|}{ 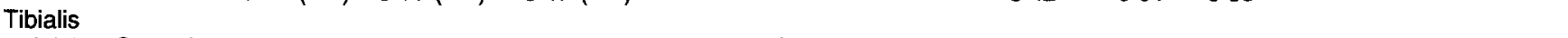 } \\
\hline Adult & $\begin{array}{l}\text { Control } \\
\text { Dex }\end{array}$ & $\begin{array}{l}3.05 \\
1.84^{\star \star}\end{array}$ & $\begin{array}{l}2.85 \\
3.21\end{array}$ & $\begin{array}{l}3.81 \\
4.74^{\star \star}\end{array}$ & 0.19 & NS & 0.01 & 0.01 & $\begin{array}{l}8.62 \\
6.05^{\star \star}\end{array}$ & $\begin{array}{l}8.45 \\
9.36\end{array}$ & $\begin{array}{l}10 \cdot 2 \\
11.0\end{array}$ & 0.43 & NS & 0.01 & 0.01 \\
\hline Old & $\begin{array}{l}\text { Control } \\
\text { Dex }\end{array}$ & $\begin{array}{l}3.84 \\
2 \cdot 40^{* *}\end{array}$ & $\begin{array}{l}3.53 \\
3.55\end{array}$ & $\begin{array}{l}4.31 \\
4.89\end{array}$ & 0.24 & NS & 0.01 & 0.01 & $\begin{array}{l}7.82 \\
5.09^{* *}\end{array}$ & $\begin{array}{l}6.58 \\
7.02\end{array}$ & $\begin{array}{l}6.81 \\
7.84\end{array}$ & 0.53 & NS & NS & 0.01 \\
\hline \multicolumn{16}{|c|}{ Extensor digitorum longus } \\
\hline Adult & $\begin{array}{l}\text { Control } \\
\text { Dex }\end{array}$ & $\begin{array}{l}4.07 \\
2.94^{* *}\end{array}$ & $\begin{array}{l}3.66 \\
3.51\end{array}$ & $\begin{array}{l}4.44 \\
4.94^{*}\end{array}$ & 0.16 & NS & 0.01 & 0.01 & $\begin{array}{l}12 \cdot 3 \\
9 \cdot 41^{\star *}\end{array}$ & $\begin{array}{l}11.5 \\
10.8\end{array}$ & $\begin{array}{l}12 \cdot 4 \\
13 \cdot 3\end{array}$ & 0.52 & NS & 0.01 & 0.01 \\
\hline Old & $\begin{array}{l}\text { Control } \\
\text { Dex }\end{array}$ & $\begin{array}{l}4.77 \\
3.58^{* *}\end{array}$ & $\begin{array}{l}4.42 \\
4.37\end{array}$ & $\begin{array}{l}4.82 \\
5.30\end{array}$ & 0.17 & NS & 0.01 & 0.01 & $\begin{array}{l}10.7 \\
8.49^{\star *}\end{array}$ & $\begin{array}{l}10.5 \\
10.2\end{array}$ & $\begin{array}{l}11 \cdot 1 \\
12 \cdot 2\end{array}$ & 0.30 & NS & 0.01 & 0.01 \\
\hline
\end{tabular}

Mean values were significantly different from those for the control group at the same stage, ${ }^{\star} P<0.05,{ }^{\star \star} P<0.01$.

$\dagger$ The values for $n$ given for gastrocnemius muscle are the same for the other variables in this muscle and for the other muscles at the same stage of slaughter in the same treatment group.

show any significant Dex-induced increase in muscle FSR at any stage of recovery.

ASR, the total amount of protein synthesized per $d$, can be calculated from FSR and the protein content of the muscle. These values are not shown because the patterns of change due to Dex and age were broadly similar to those described earlier.

The effect of Dex at both ages seems to be almost totally a reflection of the decrease of the ribosomal efficiency ( $\mathrm{mg}$ protein synthesized/mg RNA per d) since in all the fasttwitch muscles of both adult and old rats ribosomal efficiency was significantly reduced by Dex (Table 4). In contrast, with the exception of tibialis anterior muscle in the adult rats, ribosomal capacity was unaffected (Table 1).
During the recovery period, following Dex administration, ribosomal efficiency was not significantly different from controls in any of the muscles or at either age (Table 4). There were some significant effects on ribosomal capacity however, in gastrocnemius muscles of old rats at $R+3$, and in the tibialis anterior and gastrocnemius muscles of adult rats at $\mathrm{R}+7$ (Table 1 ).

\section{Oxidative muscle protein metabolism}

Adult rats did not show any change in protein synthesis in soleus muscle at any period considered (Table 5). In contrast a decrease in protein synthesis after Dex treatment 
Table 5. Fractional synthesis rate (FSR) and translational efficiency of oxidative muscles in adult and old rats given dexamethasone (Dex) in their drinking water for 6 and $5 \mathrm{~d}$ respectively, and in pair-fed controls; animals were killed at the end of treatment (DEX) or allowed to recover for $3(\mathrm{R}+3)$ or $7(\mathrm{R}+7) \mathrm{d}$

(Values are means and residual standard errors of three stages (S) for the two treatments $(T)$ )

\begin{tabular}{|c|c|c|c|c|c|c|c|c|c|c|c|c|c|c|c|}
\hline & & \multicolumn{4}{|c|}{ FSR $(\%$ per $d)$} & \multicolumn{3}{|c|}{ ANOVA: $P<$} & \multicolumn{4}{|c|}{$\begin{array}{l}\text { Translational efficiency } \\
\text { (mg protein/mg RNA per d) }\end{array}$} & \multicolumn{3}{|c|}{ ANOVA: $P<$} \\
\hline & & DEX & $R+3$ & $R+7$ & RSE & $\mathrm{T}$ & $S$ & $\mathbf{T} \times \mathbf{S}$ & DEX & $\mathrm{R}+3$ & $R+7$ & RSE & $T$ & $S$ & $\mathrm{~T} \times \mathrm{S}$ \\
\hline \multicolumn{16}{|l|}{ Soleus } \\
\hline Adult & $\begin{array}{l}\text { Control } \\
\text { Dex }\end{array}$ & $\begin{array}{l}7.13(n 9) \dagger \\
6.82(n 9)\end{array}$ & $\begin{array}{l}6.50(n 7) \\
6.69(n 7)\end{array}$ & $\begin{array}{l}6.45(n 8) \\
6.66(n 8)\end{array}$ & 0.30 & NS & NS & NS & $\begin{array}{l}9.65 \\
10.1\end{array}$ & $\begin{array}{l}8.87 \\
9.30\end{array}$ & $\begin{array}{l}9.11 \\
9.01\end{array}$ & 0.26 & NS & 0.01 & NS \\
\hline Old & $\begin{array}{l}\text { Control } \\
\text { Dex }\end{array}$ & $\begin{array}{l}7.69(n 7) \\
6.37^{\star \star}(n 7)\end{array}$ & $\begin{array}{l}6.27(n 4) \\
6.82(n 4)\end{array}$ & $\begin{array}{l}6.66(n 4) \\
6.57(n 4)\end{array}$ & 0.24 & NS & NS & 0.01 & $\begin{array}{l}8 \cdot 11 \\
7 \cdot 33\end{array}$ & $\begin{array}{l}6.50 \\
7.82^{*}\end{array}$ & $\begin{array}{l}6.74 \\
6.95\end{array}$ & 0.30 & NS & NS & 0.05 \\
\hline \multicolumn{16}{|l|}{ Heart } \\
\hline Adult & $\begin{array}{l}\text { Control } \\
\text { Dex }\end{array}$ & $\begin{array}{l}7.39 \\
8.50^{\star *}\end{array}$ & $\begin{array}{l}7.91 \\
7.72\end{array}$ & $\begin{array}{l}9.37 \\
8.76\end{array}$ & 0.24 & NS & 0.01 & 0.01 & $\begin{array}{l}10 \cdot 3 \\
12 \cdot 1^{\star}\end{array}$ & $\begin{array}{l}11 \cdot 2 \\
10 \cdot 2\end{array}$ & $\begin{array}{l}11.4 \\
10 \cdot 3\end{array}$ & 0.60 & NS & NS & 0.05 \\
\hline Old & $\begin{array}{l}\text { Control } \\
\text { Dex }\end{array}$ & $\begin{array}{l}8.74 \\
9.20\end{array}$ & $\begin{array}{l}9.20 \\
8 \cdot 87\end{array}$ & $\begin{array}{l}9.21 \\
8.46\end{array}$ & 0.23 & NS & NS & NS & $\begin{array}{l}9.27 \\
10.7\end{array}$ & $\begin{array}{l}10.0 \\
9.96\end{array}$ & $\begin{array}{l}9.79 \\
9 \cdot 25\end{array}$ & 0.57 & NS & NS & NS \\
\hline
\end{tabular}

Mean values were significantly different from those for the control group at the same stage: ${ }^{*} P<0.05,{ }^{* *} P<0.01$.

+ The values for $n$ given for soleus muscle are the same for the other variables in this muscle and for heart at the same stage of slaughter in the same treatment group.

was detected in old rats based on the significant change in FSR $(-17.1 \% v$. control, $P<0.05$, decrease at the end of the Dex treatment) or ASR $(+28.7 \% v$. control, $P<0.1$, increase at $3 \mathrm{~d}$ after Dex withdrawal). Like the changes observed in the fast-twitch muscles, these changes did not appear to involve ribosomal capacity which was unchanged (Table 2), but to be a result of changes in ribosomal efficiency $(-9.6 \%, P<0.1$, and $+20.4 \%, P<0.05, v$. control at the end of the treatment and at $\mathrm{R}+3$ respectively).

In complete contrast to the skeletal muscles, where Dex reduced the FSR, in the heart Dex increased both the FSR and ribosomal efficiency (FSR $+15 \% v$. control, $P<0.05$; ribosomal efficiency $+17 \% v$. control, $P<0.05$ ). These changes were not observed in the old animals.

\section{Discussion}

The effect of glucocorticoids on muscle protein synthesis in vivo has been widely studied in young growing animals and young adult rats. Various administration modes (subcutaneous, intraperitoneal, intravenous, oral), types of steroids (corticosterone, dexamethasone, cortisone acetate), quantities injected $(20 \mu \mathrm{g}-10 \mathrm{mg} / \mathrm{d})$ and durations of the treatment have been tested (Rannels \& Jefferson, 1980; Odedra et al. 1983; Kelly et al. 1986; Dardevet et al. 1995). These experiments were performed using either ad libitumfed or pair-fed rats. It was generally concluded that glucocorticoids are able to reduce markedly protein synthesis in oxidative glycolytic muscles in vivo. Our results confirm that this effect occurs in the fast twitch muscles of adult and old rats and that, at least as regards the gastrocnemius, the effect tends to be accentuated in old animals. This increased inhibition of protein synthesis by glucocorticoids in old rats is consistent with previous results obtained in a study made on similar animals and using the same treatment as in the present experiment; where protein synthesis was subsequently measured in epitrochlearis in vitro (Dardevet et al. 1995). In that experiment, Dex treatment decreased protein synthesis in epitrochlearis taken from old Dex-treated rats but not from adult rats, revealing the intrinsic difference in the effect of glucocorticoids on muscle protein synthesis with age. Furthermore, these in vitro experiments (and others) demonstrated that the Dex treatment induced an insulinand insulin-like growth factor-1-resistant state (Caro \& Amatruda, 1982; Holmäng \& Bjorntorp, 1992; Louard et al. 1994) which could participate in or could contribute to the decrease in protein synthesis observed in vivo. Thus, the lower protein synthesis rates may be a reflection of an impairment of the action of anabolic hormones.

The decrease in protein synthesis after Dex treatment was mainly related to an impairment in protein efficiency. This is consistent with an alteration in translation. Glucocorticoids have been shown to decrease eukaryotic initiation factor-2 (eIF-2) activity (Rannels et al. 1978). An impairment of translation is not inconsistent with the insulin resistance occurring after the glucocorticoid treatment since insulin acts in part through modification of eIF2B and eIF-4B phosphorylation (Kimball et al. 1994).

Alterations in the adaptive responsiveness to hormonal and other biochemical stimuli are characteristic of aged animals and include a decreased ability to respond to stress. For example, alterations in glucocorticoid induction of many hepatic enzymes (e.g. tyrosine aminotransferase $(E C$ 2.6.1.1), alanine aminotransferase ( $E C$ 2.6.1.2), and mitochondrial malate dehydrogenase) have been observed in aged animals (Kalimi et al. 1983). In addition, we have recently reported an alteration in the effect of glucocorticoids on the expression of some proteolytic genes in the aged epitrochlearis muscle (Dardevet et al. 1995). The glucocorticoid-induced increased expression of the $14 \mathrm{kDa}$ ubiquitin-conjugating enzyme $E_{2}$, which is involved in protein ubiquitylation, and of subunits of the $20 \mathrm{~S}$ proteasome (the proteolytic core of the $26 \mathrm{~S}$ proteasome that degrades ubiquitin conjugates) was lost in aged rats (Dardevet et al. 1995). In contrast, glutamine synthetase 
(EC 6.3.1.2) induction by glucocorticoids is preserved in skeletal muscle of aged rats (Meynial-Denis et al. 1996). Inhibition of collagen synthesis by glucocorticoids was also preserved in old human beings (Haapasaari et al. 1996). Both the work of Dardevet et al. (1995) and that reported here have shown a greater responsiveness of muscle protein synthesis to glucocorticoids in old rats. These three last findings indicate no general impairment of glucocorticoid action in aged skeletal muscle, but might indicate that effects on synthesis are preserved whilst effects on protein degradation are lost.

Garlick et al. (1989) have demonstrated that protein metabolism in muscle is highly dependent on its activity and the way the fibres are used in the muscle. For instance, soleus muscle is considered to be a postural muscle whose fibres are in frequent use. This muscle appears to be less sensitive to many factors, including glucocorticoids, than muscles such as extensor digitorum longus, gastrocnemius and tibialis anterior (Odedra et al. 1983). Consistent with this observation, we found no effect of glucocorticoids in adult soleus muscle. In contrast, in the old animals, Dex significantly decreased protein synthesis. One possible reason for this is that muscles such as the soleus are not in such constant use in the more sedentary older animals.

Many authors have shown either an anabolic effect or a lack of effect of glucocorticoids on protein metabolism in the heart (Kelly \& Goldspink, 1982; Kelly et al. 1986; Czerwinski et al. 1991). The heart is unusual, since it is the only muscle to show an increased rate of protein synthesis after glucocorticoid treatment. In agreement with these studies, an increase in FSR was observed in adult rats. This anabolic effect of glucocorticoids has been partially attributed to an indirect effect of steroid hormones through increased blood pressure which leads to a mechanical stimulation of protein synthesis in heart. In our experiments, the anabolic effect of glucocorticoids seems to be less efficient in old rats compared with adults. Florini (1989) demonstrated that this was also true in the case of the anabolic effect of thyroid hormones. Moreover, the induction of heat-shock protein gene expression by psychological stress was attenuated in ageing rats (Mobbs, 1996). Taken together, these findings support the idea that the heart muscle of old animals is less able to increase protein synthesis when challenged by a hypertrophic stimulus.

The impairment of protein synthesis in oxidative glycolytic muscle from Dex-treated rats was not maintained after Dex withdrawal. In fact, the FSR in Dex-treated adult rats was not merely restored, but exceeded the control values by day 3 of recovery in the gastrocnemius and by day 7 in the tibialis and the extensor digitorum longus. FSR in Dex-treated old rats was restored to, but not significantly above, control values, suggesting that old rats recovered less easily than adults. A similar observation was made in epitrochlearis in vitro (Dardevet et al. 1995). Whether this is due to a direct effect of the glucocorticoid or to the rate of disappearance of the glucocorticoid-induced insulin resistance is not known.

Our findings add credence to the idea that the ability to regulate muscle protein synthesis is retained into old age. Other powerful stimuli, such as hyperaminoacidaemia alone, or together with hyperinsulinaemia also elicited the same response in adult and old rats (Mosoni et al. 1995). However, there are clearly situations where the response of old animals is impaired, notably in the response of the heart to Dex, and in the response of the oxidative glycolytic muscles during the recovery period. Mosoni et al. (1995) have also observed attenuated responses in old rat muscles to fasting, refeeding and exercise.

We emphasize that glucocorticoids may play a role in ageing since there are periods of glucocorticoid hypersecretion with advanced age (Masoro, 1995) and increased sensitivity to illness. In addition, the return of circulating corticosterone to basal levels is slowed down in old stressed rats (Sapolski et al. 1983). The increased sensitivity to glucocorticoids in old rats may be explained in part by the delayed recovery in old animals after the Dex treatment and we hypothesize that the fall in the level of Dex in the blood or circulating level of Dex can be slowed down in old rats. This is known to happen to basal levels of glucocorticoids in old rats (for a review see Mobbs, 1996).

The slowing down of the rate of decrease in circulating levels of glucocorticoid with age after a stress leading to a rise in the circulating concentration may be the result of the decrease in the number of glucocorticoid receptors reported in brain (Behl et al. 1997). A modification in glucocorticoid receptor number in other tissues like muscle could explain the difference in sensitivity to glucocorticoids in different types of muscles. However, such a decrease in glucocorticoid receptor number in muscle has not yet been described.

In conclusion, we have demonstrated that glucocorticoid action on skeletal muscle protein synthesis differed markedly between the type of muscle examined and between adult and old rats. Glucocorticoids induce a more rapid reduction in muscle protein synthesis (in mixed fibre and glycolytic muscles) in aged animals, and the recovery of muscle protein synthesis is impaired.

The action of Dex induces the same decrease in protein synthesis in oxidative glycolytic and glycolytic muscles in adult and old rats (with a tendency for a larger decrease in protein synthesis in gastrocnemius muscle of Dex-treated old rats). However, the action of Dex on oxidative muscles differed in that protein synthesis of the postural soleus muscle was more affected by Dex in old than in adult rats. This suggests an impairment in contractile activity of soleus fibres in old rats which could lead to an increased sensitivity of this muscle to glucocorticoids. The opposite effect occurred in heart, where the anabolic effect of Dex appeared to be less pronounced in the old rats. Further studies are necessary.

\section{References}

Behl C, Lezoualc'h F, Trapp T, Widmann M, Skutella T \& Holsboer F (1997) Glucocorticoids enhance oxidative stressinduced cell death in hippocampal neurons in vitro. Endocrinology 138, 101-106.

Bowes SB, Jackson NC, Papachristodoulou D, Umpleby AM \& Sönksen PH (1996) Effect of corticosterone on protein degradation in isolated rat soleus and extensor digitorum longus muscles. Journal of Endocrinology 148, 501-507. 
Caro JF \& Amatruda JM (1982) Glucocorticoid-induced insulin resistance. The importance of postbinding events in the regulation of insulin binding, action, and degradation in freshly isolated and primary cultures of rat hepatocytes. Journal of Clinical Investigation 69, 866-875.

Cohn SH, Vartsky D, Yasumura S, Sawitsky A, Zanzi J, Waswani A \& Ellis KJ (1980) Compartmental body composition on totalbody nitrogen, potassium, and calcium. American Journal of Physiology 239, E524-E530.

Czerwinski SM, Kurowski TT, McKee EE, Zak R \& Hickson RC (1991) Myosin heavy chain turnover during cardiac mass changes by glucocorticoids. Journal of Applied Physiology 70, 300-305.

Dardevet D, Sornet C, Taillandier D, Savary I, Attaix D \& Grizard J (1995) Sensitivity and protein turnover response to glucocorticoids are different in skeletal muscle from adult and old rats. Lack of regulation of the ubiquitin-proteasome proteolytic pathway in aging. Journal of Clinical Investigation 96, 21132119.

Florini JR (1989) Limitation of interpretation of age-related changes in hormone levels: illustration by effects of thyroid hormones on cardiac and skeletal muscle. Journal of Gerontology 44, B107-B109.

Garlick PJ, McNurlan MA \& Preedy VR (1980) A rapid and convenient technique for measuring the rate of protein synthesis in tissues by injection of $[3 \mathrm{H}]$ phenylalanine. Biochemical Journal 192, 719-723.

Garlick PJ, Maltin CA, Baillie AGS, Delday MI \& Grubb DA (1989) Fiber-type composition of nine rat muscles. II. Relationship to protein turnover. American Journal of Physiology 257, E828-E832.

Haapasaari KM, Risteli J \& Oikarinen A (1996) Recovery of human skin collagen synthesis after short-term topical corticosteroid treatment and comparison between young and old subjects. British Journal of Dermatology 135, 65-69.

Holloszy JO, Chen M, Cartee GD \& Young JC (1991) Skeletal muscle atrophy in old rats: differential changes in the three fiber types. Mechanisms of Ageing and Development 60, 199-213.

Holmäng A \& Bjorntorp P (1992) The effects of cortisol on insulin sensitivity in muscle. Acta Physiologica Scandinavica 144, 425-431.

Kalimi M, Gupta S, Hubbard J \& Greene K (1983) Glucocorticoid receptors in adult and senescent rat liver. Endocrinology 112, 341-347.

Kelly FJ \& Goldspink DF (1982) The differing response of four muscle types to dexamethasone treatment in the rat. Biochemical Journal 208, 147-151.

Kelly FJ, McGrath JA, Goldspink DF \& Cullen MJ (1986) A morphological/biochemical study on the actions of corticosteroids on rat skeletal muscle. Muscle and Nerve 9, 1-10.

Kimball SR, Vary TC \& Jefferson LS (1994) Regulation of protein synthesis by insulin. Annual Review of Physiology 56, 321-348.

Landfield PW, Baskin RK \& Pitler TA (1981) Brain-age correlates retardation by hormonal pharmacological manipulations. Science 214, 581-584.

Louard RJ, Bhushan R, Gelfand RA, Barrett EJ \& Sherwin RS (1994) Glucocorticoids antagonize insulin's antiproteolytic action on skeletal muscle in humans. Journal of Clinical Endocrinology and Metabolism 79, 278-284.

Manchester KL \& Harris EJ (1968) Effect of denervation on the synthesis of ribonucleic acid and deoxyribonucleic acid in rat diaphragm muscle. Biochemical Journal 108, 177-183.

Masoro EJ (1995) Glucocorticoids and aging. Aging - Clinical and Experimental Research 7, 407-413.

Meynial-Denis D, Mignon M, Miri A, Imbert J, Aurousseau E, Taillandier D, Attaix D, Arnal M \& Grizard J (1996) Glutamine synthetase induction by glucocorticoids is preserved in skeletal muscle of aged rats. American Journal of Physiology 271, E1061-E1066.

Mobbs CV (1996) Neuroendocrinology of aging. In Handbook of the Biology of Aging, 4th ed., pp. 234-282 [EL Schneider and JW Rowe, editors]. New York: Academic Press.

Mosoni L, Patureau Mirand P, Houlier ML \& Arnal M (1993) Age-related changes in protein synthesis measured in vivo in rat liver and gastrocnemius muscle. Mechanisms of Ageing and Development 68, 209-220.

Mosoni L, Valluy MC, Serrurier B, Prugnaud J, Obled C, Guezennec CY \& Patureau Mirand P (1995) Altered response of protein synthesis to nutritional state and endurance training in old rats. American Journal of Physiology 268, E328E335.

Odedra BR, Bates PC \& Millward DJ (1983) Time course of the effect of catabolic doses of corticosterone on protein turnover in rat skeletal muscle and liver. Biochemical Journal 214, 617627.

Odedra BR \& Millward DJ (1982) Effect of corticosterone treatment on muscle protein turnover in adrenalectomized rats and diabetic rats maintained on insulin. Biochemical Journal 204, 663-672.

Rannels SR \& Jefferson LS (1980) Effects of glucocorticoids on muscle protein turnover in perfused rat hemicorpus. American Journal of Physiology 238, E564-E572.

Rannels SR, Rannels DE, Pegg AE \& Jefferson LS (1978) Glucocorticoid effects on peptide-chain initiation in skeletal muscle and heart. American Journal of Physiology 235, E134E139.

Sapolsky RM, Krey L \& McEwen BS (1983) The adrenocortical stress response in the aged male rat: impairment of recovery from stress. Experimental Gerontology 18, 55.

Sapolsky RM, Krey L \& McEwen BS (1986) The neuroendocrinology of stress and aging: the glucocorticoid cascade hyopothesis. Endocrine Reviews 7, 284-301.

Smith PK, Krohn RI, Hermanson GT, Mallia AK, Gartner FH Provenzano MD, Fujimoto EK, Goeke NM, Olson BJ \& Klenk DC (1985) Measurement of protein using bicinchoninic acid. Analytical Biochemistry 150, 76-85.

Tomas FM, Munro HN \& Young VR (1979) Effect of glucocorticoid administration on the rate of muscle protein breakdown in vivo in rats, as measured by urinary excretion of $\mathrm{N} \tau$-methylhistidine. Biochemical Journal 178, 139-146.

Young VR, Munro HN \& Fukagawa N (1989) Protein and functional consequences of deficiency. In Nutrition in the Elderly, pp. 65-84 [A Horwitz, DM MacFayden, H Munro, NS Scrimshaw, B Steen and TF Williams, editors]. New York: Oxford University Press. 